\title{
Relationship between marriage readiness and pregnancy planning among prospective brides
}

\author{
Novita Rahmah, ${ }^{1}$ Wiwit Kurniawati ${ }^{2}$ \\ ${ }^{1}$ Faculty of Nursing, Universitas Indonesia, Depok, West Java; ${ }^{2}$ Department of Maternity Nursing, Faculty of \\ Nursing, Universitas Indonesia, Depok, West Java, Indonesia
}

\begin{abstract}
Background: The growing marriage rates need to be followed with marriage readiness and pregnancy planning to become parents. The readiness of marriage includes age readiness, physical, financial, mental, emotional, social, moral, interpersonal, intellectual, and life skills. Unprepared marriage can have an impact on domestic violence and divorce. The readiness of marriage should be balanced with the existence of important pregnancy planning carried out to realize reproductive rights responsibly and the government program movement 1000 The First Day of Life as a golden periode of child development, and avoid unplanned pregnancy in 4T conditions. Marriage readiness of prospective bride affects the readiness to maintain health of children in the future.

Design and Methods: This research aimed to determine the relationship between marriage readiness and pregnancy planning among prospective brides. A correlative descriptive design with a cross-sectional method is used with a convenience sampling technique in determining the respondents, and obtained a total of 258 respondents.
\end{abstract}

Results: The results showed a meaningful relationship between marital readiness and pregnancy planning $(p=0.000$, $\alpha=0.05)$.

Conclusions: This study recommends education of pregnancy planning and readiness before marriage, both physical and psychological, with interactive media and nurse cooperation with community cadres in socialization on wedding preparation and preconceptions that are not only attended by prospective brides, but also women of childbearing age and adolescence in minimizing misinformation in unmarried women.

\section{Introduction}

Early developments include getting married and forming a family through marriage, which can occur after the prospective bride and groom both find a partner that fits the criteria and has the same goals in living life simultaneously. This life together in marriage requires responsibility and includes many aspects of life. ${ }^{1}$ As the population increases, there will also be an increase in the number of individuals in adulthood who will carry out developmental tasks to get married. BPS data for 2017 recorded the number of marriages in Indonesia, namely $1,936,934 .^{2}$ Based on the marital status that has been registered at the Religious Affairs Office in Special Capital District of Jakarta Region in 2018, there was a significant increase totaling 58,616 marriages. Therefore, it is necessary to examine it from the prospective bride and groom perspective, because desire to get married soon but not paying attention to mental, emotional, and social readiness or even being at an age that is still facing an identity crisis shows that there is still unpreparedness for marriage. Unpreparedness for marriage can lead to conflict, domestic violence, and divorce. ${ }^{3}$

The high number of marriages in Indonesia, especially Capital District of Jakarta, must also be balanced with increased marriage readiness. The readiness for marriage includes age, physical, financial, mental, emotional, social, moral, interpersonal, intellectual, and life skills readiness. ${ }^{4}$ Research by Amalia and Siswantara's in Public Health Care Center of Pucang Sewu Surabaya showed as many as $62.5 \%$ brides still have little knowledge about reproductive health. ${ }^{5}$ Furthermore, Sunarti, Simanjuntak, Rahmatin, and Dianeswari's show that the readiness to marry a wife $(59.6 \%)$ is lower than the readiness to marry a husband $(63.2 \%),{ }^{6}$ which is related to fulfilling family duties.

The prospective bride needs to consider readiness from biological, psychological and socio-cultural perspectives. Biological readiness is by maintaining physical health conditions, psychological aspects by preparing intrapersonal and interpersonal relationships in facing new roles and tasks and socio-cultural aspects with financial readiness in managing family life. ${ }^{7}$ In addition, there are several prenuptial preparations that the bride and groom need to undertake, including physical, psychological, economic, social, healthcare and reproductive health. ${ }^{8}$

Increasing marriage rates also have an impact on birth rates. The birth rate of babies in Jakarta in 2015 was 179,001 births, with an increase in 2018 to 181,572 . There are many ways to plan peo-

Significance for public health

The number of marriages in Indonesia, especially in Jakarta, has increased significantly. The high number of marriages needs to be balanced with readiness for marriage where the prospective bride and groom think more about the concept of marriage than post-marriage life and becoming parents. Unpreparedness for marriage can lead to conflict in marriage, domestic violence, and divorce. Lack of readiness to marry occurs due to lack of planning. Family planning should be carried out in marriage, one of which is planning in terms of having children, the number of children you want, the distance between pregnancies, when to stop having children, safe use of contraception, as well as consideration of the prone age of pregnancy for women who want pregnancy and have children. Through pregnancy planning, the bride will be able to realize reproductive rights responsibly, which can support government policies related to family planning. This research is expected to provide an overview of new knowledge and strengthen previous references regarding marriage readiness and pregnancy planning. 
ple pregnancies. Some of them are not using contraception. Based on data, 222 million women in the world do not use adequate contraceptive methods. ${ }^{9}$ Pregnancy planning is vital to avoid unplanned pregnancy. Each year, 41\% of the world's 208 million pregnancies are unplanned and 4 out of 10 women in the world report that their pregnancy is not planned. ${ }^{10}$ Couples are supposed to have the readiness to marry and make preparations for marriage as well as planning in terms of having children, the number of children desired, the interval between pregnancies, when to stop having more children, safe use of contraceptives, as well as consideration of the age at risk of pregnancy for women who want pregnancy and have children. There were some articles discuss similar issues from different perspective or in different region of studies, but there is no related research about the relationship between marriage readiness and pregnancy planning among prospective brides in Jakarta. Therefore, it is crucial to research marriage readiness with pregnancy planning for the prospective bride.

\section{Design and Methods}

The design of this study used a cross-sectional study approach involving 258 female candidates who met the criteria. This research's criteria are prospective brides, have an identity card (KTP) of Jakarta, and who are willing to be respondents in the study, questionnaires were distributed through various social media platforms. At the beginning, respondents can choose on the approval page whether they are willing or not to fill out the questionnaire in accordance with research ethics.

The data collection tool used an instrument in the form of a questionnaire used to measure marriage readiness and measure pregnancy planning level with the London Measure of Unplanned Pregnancy (LMUP). The reliability test used Cronbach's alpha with the reliability value on the marriage readiness questionnaire of 0.734 and pregnancy planning 0.779 .

The data were analysed using univariate and bivariate analysis. Univariate analysis was used to describe the characteristics (age, ethnicity, education, occupation, and economy or income), the independent variable (readiness for marriage), and the dependent variable (pregnancy planning). The bivariate analysis involved two variables using the Chi-Square test to determine the relationship between marriage readiness and pregnancy planning for the bride.

Data collection was carried out after this research obtained a permit and obtained the results of the ethical review from the Faculty of Nursing University of Indonesia Number SK152/UN2.F12.D1.2.1/ETIK 2020 and Research Recommendation Number 187/AF.1.2/-1.862.9/e/2020 from DPMPTSP DKI Jakarta. The research permit was submitted by the Ministry of Religion of Jakarta with Number B-3706/Kk.09.1/1/HM.003/ 06/2020 and Religious Affairs Office Jakarta Region. Permission to the Head of Religious Affairs Office was asked to obtain contact information for registered brides. After obtaining contact data for the prospective bride, the questionnaire was distributed online via Google Form. The data collected were then rechecked and given a code. The data were then processed into information to answer the research objectives. The data processing process in this study used SPSS.

\section{Results}

The results showed that $68.2 \%$ of respondents were ready for marriage while 82 respondents $(31.8 \%)$ were not ready to marry. Based on the respondent's age, not ready to marry was indicated by the respondents in their late teens (17-20 years). When viewed from the number of respondents, most ethnic groups came from the Javanese ethnic group, as many as 109 respondents, followed by

Table 1. Analysis results of marriage readiness according to demographic data $(n=258)$.

\begin{tabular}{|c|c|c|c|c|c|}
\hline \multirow[t]{3}{*}{ Variable } & \multicolumn{4}{|c|}{ Marriage readiness } & \multirow{3}{*}{ Total } \\
\hline & \multicolumn{2}{|c|}{ Ready } & \multicolumn{2}{|c|}{ Unready } & \\
\hline & n & $\%$ & n & $\%$ & \\
\hline \multicolumn{6}{|l|}{ Age } \\
\hline Late adolescence & 8 & 28.6 & 20 & 71.4 & 28 \\
\hline Young adulthood & 152 & 71.4 & 61 & 28.6 & 213 \\
\hline Late adulthood & 16 & 94.1 & 1 & 5.9 & 17 \\
\hline \multicolumn{6}{|l|}{ Ethnicity } \\
\hline Betawi & 54 & 69.2 & 24 & 30.8 & 78 \\
\hline Java & 71 & 65.1 & 38 & 34.9 & 109 \\
\hline Sunda & 20 & 66.7 & 10 & 33.3 & 30 \\
\hline Minang & 15 & 62.5 & 9 & 37.5 & 24 \\
\hline Batak & 4 & 100 & 0 & 0 & 4 \\
\hline Other & 12 & 92.3 & 1 & 7.7 & 13 \\
\hline \multicolumn{6}{|l|}{ Educational level } \\
\hline Primary & 2 & 40 & 3 & 60 & 5 \\
\hline Secondary & 54 & 70,1 & 23 & 29.9 & 77 \\
\hline Higher & 120 & 68.2 & 56 & 31.8 & 176 \\
\hline \multicolumn{6}{|l|}{ Employment status } \\
\hline Unemployed & 46 & 49.5 & 47 & 50.5 & 93 \\
\hline Informal employee & 11 & 50 & 11 & 50 & 22 \\
\hline Formal employee & 119 & 83.2 & 24 & 16.8 & 143 \\
\hline \multicolumn{6}{|l|}{ Income } \\
\hline Less than provincial minimum wage & 82 & 58.2 & 59 & 41.8 & 141 \\
\hline Average & 94 & 80.3 & 23 & 19.7 & 117 \\
\hline Total & 176 & 68.2 & 82 & 31.8 & 258 \\
\hline
\end{tabular}


Table 2. Analysis results of pregnancy planning according to demographic data $(n=258)$.

\begin{tabular}{|c|c|c|c|c|c|}
\hline \multirow[t]{3}{*}{ Variable } & \multicolumn{4}{|c|}{ Pregnancy planning } & \multirow{3}{*}{ Total } \\
\hline & \multicolumn{2}{|c|}{ Ambivalent } & \multicolumn{2}{|c|}{ Planned } & \\
\hline & n & $\%$ & n & $\%$ & \\
\hline \multicolumn{6}{|l|}{ Age } \\
\hline Late adolescence & 13 & 46.4 & 15 & 53.6 & 28 \\
\hline Young adulthood & 66 & 31 & 147 & 69 & 213 \\
\hline Late adulthood & 2 & 11.8 & 15 & 88.2 & 17 \\
\hline \multicolumn{6}{|l|}{ Ethnicity } \\
\hline Betawi & 25 & 32.1 & 53 & 67.9 & 78 \\
\hline Jawa & 39 & 35.8 & 70 & 64.2 & 109 \\
\hline Sunda & 11 & 36.7 & 19 & 63.3 & 30 \\
\hline Minang & 5 & 20.8 & 19 & 79.2 & 24 \\
\hline Batak & 0 & 0 & 4 & 100 & 4 \\
\hline Others & 1 & 7.7 & 12 & 92.3 & 13 \\
\hline \multicolumn{6}{|l|}{ Educational level } \\
\hline Primary & 1 & 20 & 4 & 80 & 5 \\
\hline Secondary & 21 & 27.3 & 56 & 72.7 & 77 \\
\hline Higher & 59 & 33.5 & 117 & 66.5 & 176 \\
\hline \multicolumn{6}{|l|}{ Employment status } \\
\hline Unemployed & 41 & 44.1 & 52 & 55.9 & 93 \\
\hline Informal & 8 & 36.4 & 14 & 63.8 & 22 \\
\hline Formal & 32 & 22.4 & 111 & 77.6 & 143 \\
\hline \multicolumn{6}{|l|}{ Income } \\
\hline Less than provincial minimum wage & 55 & 39 & 86 & 61 & 141 \\
\hline Average & 26 & 22.2 & 91 & 77.8 & 117 \\
\hline Total & 81 & 31.4 & 177 & 68.6 & 258 \\
\hline
\end{tabular}

the Betawi ethnic group with 78 respondents. Based on education, respondents who were not ready to marry were at the basic education level of $60 \%$. Based on the characteristic of the work, ready to get married respondents indicated the respondents with a formal job by $83.2 \%$, and earnings according to Jakarta Provincial Minimum Wage, which is $80.3 \%$. Analysis results of marriage readiness according to demographic data can be seen on Table 1 .

The results of pregnancy planning showed $68.6 \%$ of respondents had a planned pregnancy plan, while $31.4 \%$ of respondents had an ambivalent pregnancy plan. Based on respondent's age, a planned pregnancy planning is at the end of the adult age of $88.2 \%$ and pregnancy planning ambivalent majority are in their late teens by $46.4 \%$. When viewed by ethnicity, all ethnic groups already had a planned pregnancy plan, with more than $63 \%$. At the education level, most respondents at all levels of education, namely, more than $66 \%$, already had a planned pregnancy plan. The majority of respondents who have a planned pregnancy planning with formal employment amounted to $77.6 \%$ based on the work. Based on the economy, both respondents having an economy less than the UMP and, according to the UMP, the majority have a planned pregnancy plan, namely $61 \%$ and $77.8 \%$. Analysis results of pregnancy planning according to demographic data can be seen on Table 2.

The calculation results with Pearson Chi-Square show the calculation of the relationship between the variable readiness to marry and the variable pregnancy planning and can be seen from the Pearson Chi-Square value in the Asymp column. Sig. there is a pvalue of 0.000 where $\alpha=0.05$. Then, the conclusion is $\mathrm{p}$-value $<\alpha$ so that $\mathrm{H} 0$ is rejected (there is a significant relationship between readiness to marry and pregnancy planning). Results of Chi-Square test on the relationship of marriage readiness and pregnancy planning can be seen on Table 3.
Table 3. Results of Chi-Square test on the relationship of marriage readiness and pregnancy planning $(n=258)$.

\begin{tabular}{|c|c|c|c|c|}
\hline Marriage readiness & Pregnanc & inning & Total & p \\
\hline & Ambivalent & Planned & & \\
\hline Unready & 42 & 40 & 82 & 0.000 \\
\hline Ready & 39 & 137 & 176 & 0.000 \\
\hline Total & 81 & 177 & 258 & 0.000 \\
\hline
\end{tabular}

\section{Discussion}

The study results on the description of marriage readiness show that, in general, the prospective bride and groom in Jakarta are ready to marry, although there is still a third of the total number of respondents who are not ready to marry. Readiness for marriage shows a state of being willing or ready to have a relationship with a partner, ready to manage a family, ready to take care of children, and ready to accept responsibilities as husband and wife. ${ }^{11}$ The description of the readiness to marry the prospective bride in Jakarta when viewed from the respondent's characteristics, based on the age of the respondent, not ready to marry is shown in the respondents who are in their late teens while ready to marry is shown in adulthood. This is in line with the BKKBN age limit, where the ideal marriage is 25 years for men and 21 years for women. This age is considered the best age because the reproductive organs are ready and, on average, the person can think and act in an adult manner. ${ }^{12}$ Furthermore, based on ethnicity, this data follow the location of the research conducted in Jakarta. Based on the 2010 Population Survey, Capital District of Jakarta Province is dominated by the Javanese, totaling 3,453,453 people, the Betawi ethnic group as the original ethnic group of Jakarta totaling 2,700,722 people, and the Sundanese ethnic group 1,395,025 million. 
Intellectual readiness is needed in readiness to marry. Intellectual unpreparedness indicates the respondent's lack of interest in reading books, news, or information about related knowledge. The high level of intellectual readiness is an asset to building better resources. ${ }^{6}$ Based on Tsania, Sunarti, and Krisnatuti's research, there is a positive relationship between the length of education and child development. ${ }^{13}$ This can happen because the higher the level of education, the individual can reduce gender gaps, be more mature, and be more prepared before deciding to get married. Education also fosters good family development in decision-making and childcare. The level of education also influences marriage readiness, where the higher the education, the higher the individual's readiness to marry. ${ }^{14}$

This study's results are in line with research by Septyandari's, showing that the better the individual planning, the better the readiness to marry the individual. ${ }^{15}$ The results of Oktanina's research conducted on 96 young adult women who work show a positive relationship between work commitment and marriage readiness where the higher the work commitment, the higher the readiness to marry. ${ }^{16}$ The research results on the description of pregnancy planning show that, in general, the prospective bride in Jakarta already has a planned pregnancy plan. A well-planned pregnancy process will have a positive impact on the fetus's condition and the psychological and physical adaptations of the mother. Therefore, pregnancy planning should be done before pregnancy (preconception). Unplanned pregnancy that happens at the age of adolescence can increase the risk of maternal mortality, and infant mortality rates 24 times higher at $30 \%$. At the age of less than 20 years, it is necessary to postpone pregnancy because the pelvis and uterus condition are not physically developed optimally. Furthermore, they are at risk of developing anemia. Adults also have mature thoughts BKKBN and FEMA IPB's compared to the age of teenagers, who tend to have an unstable mindset, so that the adult can have a planned pregnancy planning and more members prepare how to care for the child. ${ }^{17}$

The prospective bride and groom will have a pregnancy plan if they know about the importance of pregnancy planning so that a planned pregnancy can be owned by respondents who have good knowledge about health, especially the health of mothers and babies and the impact of not doing pregnancy planning. The study results are in line with the research by Herziasyam's, showing that there is no significant relationship between maternal education and maternal readiness to face pregnancy. ${ }^{18}$ However, there is a significant relationship between the level of knowledge and the level of information exposure with the readiness of the mother to face pregnancy.

This study's results are also in line with Saptarini and Suparmi's research, namely that women who have jobs have more consideration in planning pregnancy by thinking of alternative ways to prevent unplanned pregnancies, which are considered to hinder work careers. ${ }^{19}$ Furthermore, based on the economy, both respondents who have an economy less than the Provincial Minimum Wage and according to the UMP majority have a planned pregnancy plan, namely $61 \%$ and $77.8 \%$, respectively. Individuals who have an economy less than the Provincial Minimum Wage Capital District of Jakarta may not be financially ready, especially as the Jakarta Region, as the country's capital city, has a Provincial Minimum Wage of Rp4,267,349. Based on 2019 BPS data, the highest average Provincial Minimum Wage is in the East Jakarta administrative area, Rp4,719,561, while the lowest average Provincial Minimum Wage is in the West Jakarta administrative area of Rp3,625,171. ${ }^{20}$ This figure is high compared to several other regions in Indonesia.
The relationship between marriage readiness and pregnancy planning for future brides in Jakarta has been studied for the first time, so there has been no previous research that supports the results of this study. However, Herziasyam's study explained that couples' financial readiness in facing pregnancy would greatly influence the mother's opinion regarding pregnancy readiness. ${ }^{18}$ Satisfactory financial readiness as a dimension of readiness for marriage is related to meeting needs starting from preconception preparation, pregnancy, birth, to childcare.

Marriage readiness can also be an essential indicator of the quality of child development and family success, where, when entering marriage, the bride and groom must also be ready with new roles and duties, including in terms of taking care of children. A child's presence can be a problem in itself in a family if there is no satisfactory readiness from both partners, especially the readiness of the prospective bride who will become a wife and mother for her child. Both partners must have a mutually agreed-upon method of all things, including childcare and planning. ${ }^{13}$ Furthermore, based on Kim's research, the lack of readiness to marry can impact family instability, which can affect children's behavior and emotions. ${ }^{21}$ Conflicts can also reduce cognitive development in children aged under five. Furthermore, based on Tsania et al.'s research, there is a positive relationship between readiness to marry and child development. ${ }^{13}$

The readiness to get marriage the prospective bride will affect women's readiness to maintain their children's health. If the maintenance is not carried out effectively, there will be an increase in child mortality, but this can be minimized by doing pregnancy planning. The prospective bride and groom's efforts to have healthy and quality offspring are that every bride and groom needs to have a pregnancy plan. Based on the Minister of Health Regulation No. 97/2014, the prospective bride and groom are the target of intervention in health services during the pre-pregnancy or preconception period, aiming to have a healthy pregnancy.

\section{Conclusions}

Based on the study results, the description of the readiness to marry the prospective bride in Capital District of Jakarta showed that in general, prospective brides in Jakarta are ready to get married and have a planned pregnancy plan, although there are still a third of the total number of respondents who are not ready to get married, and indicate that there is a significant relationship between readiness to marry and pregnancy planning. This can be seen from the Pearson Chi-Square test results, namely the p-value $<\alpha$ of 0.000 .

For services, it is suggested that these results become the need for more in-depth socialization of marriage readiness and pregnancy planning for the prospective bride and future husbands, couples of childbearing age, and unmarried teenagers. Besides, nursing services can also create web innovations or applications that can be opened through gadgets and other interactive media in developing education for the bride and groom so that they can access information wherever and whenever they are more effective and efficient and can optimize family harmony and roles as husband and wife, in preparing for childcare and development.

It is hoped that education can be carried out as early as possible for adolescents and early adults through the school environment, campus, and in the community regarding things that need to be prepared before marriage and planned pregnancy planning so that it is expected to be a role model for the community when providing education. 
Nurse researchers are expected to use the results of this research on marriage readiness and pregnancy planning and it can be discussed in more depth, both in terms of the variables and the research design. In addition, similar research can also be carried out with different target respondents to generalize the results of research, such as students and women of childbearing age. Research can also be undertaken in the factors that influence and comparisons of readiness to marry with pregnancy planning for the bride and groom in rural and urban areas to compare the two different conditions of society.

Correspondence: Wiwit Kurniawati, Department of Maternity Nursing, Faculty of Nursing, Universitas Indonesia, Jalan Prof. Dr. Bahder Djohan, UI Depok Campus, Depok, West Java 16424 , Indonesia. Tel. +62.21.78849120 - Fax: +62.21.7864124.

E-mail: wiwit.k@ui.ac.id

Key words: Marriage; planning; pregnancy; prospective.

Contributions: NR: concept and design, analysis and interpretation of data, drafting revision of manuscript, and final approval of the version to be published; WK: supervised conceptualization and design the study, revising it critically for important intellectual content, and final approval.

Conflict of interest: The authors declare that they have no conflict of interest.

Acknowledgments: We express our thanks to Direktorat Riset and Pengembangan Universitas Indonesia who granted Funds for PUTI Prosiding 2020 with number NKB-3445/UN2.RST/HKP.05.00/2020. The researchers also would like to thank the Capital District of Jakarta government agencies who have supported by giving permission in the research process and respondents who have participated in this research by being willing to fill out the questionnaire.

Ethics approval and consent to participate: This study has been approved by Ethics Committee of Faculty of Nursing Universitas Indonesia, Depok with Number: SK-152/UN2.F12.D1.2.1/ETIK 2020 and Research Recommendation Number 187/AF.1.2/-1.862.9/e/2020 from DPMPTSP DKI Jakarta. For respondent who participated in the research, fill out the informed consent form

Availability of data and materials: The datasets analyzed in this study are available from the corresponding author on reasonable request.

Conference presentation: This final manuscript has been presented at $7^{\text {th }}$ Virtual Biennial International Nursing Conference, Faculty of Nursing, Universitas Indonesia on September $24^{\text {th }}$, October $30^{\text {th }}$, November $16^{\text {th }} 2020$.

Received for publication: 27 July 2020.

Accepted for publication: 7 May 2021

C Copyright: the Author(s), 2021

Licensee PAGEPress, Italy

Journal of Public Health Research 2021; 10(s1):2405

doi:10.4081/jphr.2021.2405

This work is licensed under a Creative Commons Attribution NonCommercial 4.0 License (CC BY-NC 4.0).

\section{References}

1. Pasongli I, Noviekayati IGAA, Saragih S. [Triangulasi cinta, keharmonisan keluarga, dan kesiapan menikah pada dewasa muda yang berpacaran (Triangulation of love, family harmony, and readiness to marry in dating young adults)].[Article in
Indonesian]. Biopsikososial 2017;1:65-80.

2. Statistics Indonesia. [Nikah, talak dan cerai, serta rujuk (pasangan nikah), 2007 (Marriage, divorce, and reconciliation (marriage partner), 2007]. in Indonesian]. Jakarta: Statistics Indonesia; 2017. Available from: https://www.bps.go.id/indicator/27/176/4/jumlah-nikah-talak-dan-cerai-serta-rujuk.html

3. Ministry of Health, Republic of Indonesia. [Buku saku: kesehatan reproduksi dan seksual bagi calon pengantin (Pocket book: reproductive and sexual health for the bride and groom)].[Book in Indonesian]. Jakarta: Ministry of Health Republic of Indonesia; 2018.

4. Mashuri S. [Kursus pranikah (persiapan kehidupan berkeluarga) (Premarital courses (preparation for family life). Jakarta: Population and Family Planning Board; 2020. Available from: http://ntb.bkkbn.go.id/?p=1695

5. Amalia R, Siswantara P. [Efektivitas peyuluhan kesehatan reproduksi pada calon pengantin di Puskesmas Pucang Sewu Surabaya (The effectiveness of reproductive health counseling for future brides at Pucang Sewu Health Center, Surabaya)].[Article in Indonesian]. Jurnal Biometrika dan Kependudukan 2018;7:29-38.

6. Sunarti E, Simanjuntak M, Rahmatin I, Dianeswari R. [Kesiapan menikah dan pemenuhan tugas keluarga pada keluarga dengan anak usia prasekolah (Readiness for marriage and fulfillment of family duties in families with preschool children)].[Article in Indonesian]. Jurnal Ilmu Keluarga dan Konsumen 2012;5:110-9.

7. Mawaddah S, Safrina L, Mawarpuri M, Faradina S. [Perbedaan kesiapan menikah pada dewasa awal ditinjau dari jenis kelamin di Banda Aceh (Differences in readiness to marry in early adulthood in terms of gender in Banda Aceh)].[Article in Indonesian]. Jurnal Empati 2019;8:320-8.

8. Kurniawati W, Afiyanti Y. Establishing healthy family and offspring on prospective bridegroom: a qualitative analysis. Enferm Clin 2019;29:855-61.

9. Hall JA, Barrett G, Copas A, Stephenson J. London measure of unplanned pregnancy: guidance for its use as an outcome measure. Patient Relat Outcome Meas 2017;8:43-56.

10. World Health Organization. Policy brief - preconception care: maximizing the gains for maternal and child health. Geneva: World Health Organization; 2013. Available from: https://www.who.int/maternal_child_adolescent/documents/pr econception_care_policy_brief.pdf

11. Hamdi MR, Syahniar, Afdal, Ardi Z. [Kesiapan menikah mahasiswa ditinjau dari jenis kelamin, latar belakang budaya, dan sosial ekonomi (Students' readiness to marry in terms of gender, cultural background, and socioeconomic background)].[Article in Indonesian]. Jurnal Penelitian Guru Indonesia 2019;4:76-85..

12. Population and Family Planning Board. [Nikah muda (The young marriage)].[in Indonesian]. Jakarta: Population and Family Planning Board; 2018. Available from: https://www.bkkbn.go.id/detailpost/nikah-muda

13. Tsania N, Sunarti E, Krisnatuti D. [Karakteristik keluarga, kesiapan menikah istri, dan perkembangan anak usia 3-5 tahun (Family characteristics, readiness to marry a wife, and development of children aged 3-5 years)].[Article in Indonesian]. Jurnal Ilmu Keluarga dan Konsumen 2015;8:28-37.

14. Fiqi AN. [Hubungan antara religiusitas Islam dan kesiapan menikah pada dewasa muda (The relationship between Islamic religiosity and readiness to marry in young adults)].[Thesis in Indonesian]. Depok: Universitas Indonesia; 2016.

15. Septyandari C. [Hubungan antara perencanaan karir dan kesiapan menikah pada wanita dewasa muda yang bekerja (The 
relationship between career planning and marriage readiness in working young adult women)].[Thesis in Indonesian]. Depok: Universitas Indonesia; 2013.

16. Oktanina N. [Hubungan antara komitmen kerja dan kesiapan menikah pada wanita dewaa muda yang bekerja (The relationship between work commitment and readiness to marry in working young women)].[Thesis in Indonesian]. Depok: Universitas Indonesia; 2013.

17. Population and Family Planning Board, FEMA IPB. [Siap nikah (Ready to get married)].[in Indonesian]; 2019. Available from: https://ikk.fema.ipb.ac.id/index.php/siap-nikah/

18. Herziasyam JO. [Kesiapan ibu menghadapi kehamilan dan faktor-faktor yang mempengaruhinya (The readiness of the mother to face pregnancy and the factors that influence it)].[Article in Indonesian]. Jurnal Ilmu dan Teknologi Kesehatan 2016;3:147-59.

19. Saptarini I, Suparmi. [Determinan kehamilan tidak diinginkan di Indonesia (A determinant of unwanted pregnancy in Indonesia)].[Article in Indonesian]. Jurnal Kesehatan Reproduksi 2016;7:15-24.

20. Integration of Statistical Processing and Dissemination. [Provinsi DKI Jakarta dalam angka (DKI Jakarta Province in figures 2020)].[in Indonesian]. Jakarta: Central Bureau of Statistics of Jakarta Provincea; 2020. 798 p.

21. Kim HS. Consequences of parental divorce for child development. Am Sociol Rev 2011;76:487-511. 